\title{
DZIKIR CAN REDUCE LABOR PAIN LEVEL
}

\author{
Ai Nur Zannah \\ Program studi kebidanan program sarjana, STIKES dr. Soebandi, Jember
}

\begin{abstract}
Labor pain is a physiological condition that began at the first stage of labor (laten and active phase). Pain comes from uterine contractions and cervical dilation in an attempt to pave the way for birth and encourage babies to be born. Experts find pharmacological and non-pharmacological ways to reduce pain in labor, one of them is Dzikir guided by childbirth helper (midwife). The purpose of this study was to analyze the differences of labor pain level on mother in latent phase before and after applying Dzikir. Subjects were 15 accidentally selected mothers in labor latent phase on March - April in PMB "S" Puger Jember. The design of this study uses a quasi-experimental one group pre-posttest. Results showed significant decreased pain level of mothers after doing Dzikir significantly $(\mathrm{Z}=-3,578, \mathrm{p} \leq 0.001)$. In conclusions, there are differences of labor pain level on mother in latent phase before and after applying Dzikir.
\end{abstract}

Keywords: Dzikir, Labor Pain Level

\section{INTRODUCTION}

Pregnant women commonly worry about the pain they will experience during labor and birth and how they will react to and deal with that pain. Many physiologic, emotional, psychosocial, and environmental factors influence the nature and degree of pain experienced by the laboring woman and how she will respond to and cope with the pain.(Lowdermilk et al., 2013). Pain is a stressor that can cause stress and tension where individuals can respond biologically and behaviorally that causes physical and psychological responses, which if excessive can cause anxiety, fear, and tension so as to stimulate the production of prostaglandin hormones that can reduce the body's ability to withstand pain(Corwin, 2009)

A variety of nonpharmacologic and pharmacologic methods can help the woman or the couple cope with the discomfort of labor. The methods selescted depend on the situation, availability, and the preferences of the woman and her health care provider. ${ }^{1}$ Many nonpharmacological techniques for pain relief in Labor have been used over the centuries, including both psychological and physical methods. Unfortunately, there is minimal evidence for the efficacy of any of these methods, one of them is Dzikir (Olsen, 2017). Dzikir is a care with the approach of spiritual belief in Islam, namely by the technique of remembering Alloh SWT. That is a series of sentences spoken as a servant of Alloh's 
creation who has a sound mind to always remember God in a state of pleasure and sadness and health and pain, done with a heart full of sincerity so as to show that he got guidance from Allah SWT(Saleh, 2018). The job of a health worker including a midwife is to help meet the bio-psycho-social-spiritual needs of the clients we care for, including childbirth midwifery care in reducing labor pain. Dzikir gives balance to keep the body comfortable, foster calmness, patience, and encourage in the self in passing the pain suffered. In surah Ar-Ra'd: 28 is explained "Who have believed and whose hearts have rest in the remembrance of Allah. Verily in the remembrance of Allah do hearts find rest"(Idris, 2016). Studies have shown that people who are religious, devout in worship, praying and praying are much less likely to experience stress, anxiety, and depression than nonreligious ones. While Herrbert Benson's research shows that Dzikir words can be one of the focus phrases (words that become the focal point of attention) in the process of healing patients from anxiety, fear, even physical complaints such as headaches(Sanusi, 2012). Based on the above background, the researcher is interested in conducting research on the effect of Dzikir therapy on first stage labor pain.

\section{METHODS}

This research uses a pre-exprimental research design of one group pretest-posttest. The subject group is observed before intervention, then observed again after intervention. The population of this study is all maternity mothers at PMB S Puger Jember, with accidental sampling in March-April. Analysis conducted after data collected before and after using Dzikir intervention to determine differences in pain levels used Wilcoxon Signed Ranks Test analysis(Notoatmodjo, 2012)

\section{RESULTS}

Data collection using 15 respondents measured pain scale before and after dhikr intervention includes general data and specific data described in the following table:

Table 1. Characteristics of Research Subjects

\begin{tabular}{lcc}
\hline \multicolumn{1}{c}{ Karakteristik } & Jumlah & Persentase \\
\hline Usia: & 1 & \\
$<20$ th & 12 & $7 \%$ \\
$20-35$ th & 2 & $80 \%$ \\
$>35$ th & & $13 \%$ \\
\hline Pekerjaan: & 11 & \\
IRT & 3 & $73 \%$ \\
Swasta & 1 & $20 \%$ \\
PNS & & $7 \%$ \\
\hline
\end{tabular}

Table 1 shows the majority of respondents (80\%) are at reproductive age (20-35 years), although there is still a risk age too young ( $<20$ years) $7 \%$ and too old ( $>35$ years) $13 \%$. While the majority of respondents' occupations are housewives (73\%). 
Table 2. Pain levels before and after Dzikir intervention

\begin{tabular}{cccc}
\hline \multirow{2}{*}{ Pain Levels } & \multicolumn{2}{c}{ Subjects } & \multirow{2}{*}{ P Value } \\
\cline { 2 - 3 } & Pretest & Posttest & \multirow{2}{*}{$<0.001^{*}$} \\
\hline Mean & 5.73 & 1.47 & 1 \\
\hline Median & 6 & 0.516 & \\
\hline Std. Deviation & 0.458 &
\end{tabular}

*nilai p didapatkan dari uji Wilcoxon

Based on table 2 above, shows before intervention the average pain level was on a scale of 6 and after the intervention Dzikir pain levels decreased on average on a scale of 1 . After a statistical test Wilcoxon $\mathrm{Z}$ value calculate -3.40 was greater than $\mathrm{Z}$ table 1.96 (negative value is not taken into account because of the absolute price) with a value of $p<0.001$. Thus Dzikir affects the decrease in in the mother during childbirth.

\section{DISCUSSION}

Pain according to the International Association for Study of Pain is subjective sensory and emotional unpleasant related to actual or potential tissue damage and causes the individual to react to relieve pain. Pain is an integral part of childbirth due to emotional tension, pressure on nerve endings, tension in tissues and joints and hypoxia of the uterine muscles during and after long and painful contractions(Mary, 2015).

Experts found a way to reduce pain in childbirth, which is a pharmacological and non-pharmacological way. Pharmacological means are by administering analgesic drugs, but there are some analgesic drugs that have an adverse effect on the fetus. Therefore, many developed non-pharmacological ways to overcome pain in childbirth. Dzikir can be a non-pharmacological method from the spiritual side to reduce the anxiety felt during childbirth due to labor pain. The anxiety of giving birth in this study was reduced after Dzikir, marked by the absence of hysterical screaming reactions in the mother giving birth. This can facilitate the delivery process because there is no muscle tension so that cervical dilation occurs and facilitates the decline of the baby's head(Mander, 2010).

The meaning contained in the Dzikir; Allah, Subhanallah, Alhamdulilah, Allahu Akbar, Lahaula wala quwwata illa billah, and Asmaul Husna among others: a form of submission to Alloh SWT, thus giving peace of mind; a form of repentance request to Alloh SWT so that it will strengthen a person in the face of challenges that will occur such as death and complications due to illness experienced; a form of gratitude to God, thus giving positive meaning to each event, and being patient with difficulties(Newberg. A., \& Waldman, 2013). When someone always says positive sentences in Dzikir, positive emotions will arise which can stimulate limbic work to produce endorphines. Dzikir can provide benefits to reduce the secretion of the hormone cortisol, balance the work of the brain and reduce the down-regulator of GABA receptors, as well as harmony in the body and releasing endorphin hormones. Endorphines are able to cause feelings of euphoria, happiness, comfort, create calm and improve one's mood so that a person energizes through pain(Suryani, 2013).

Based on table 2 in the results, it states that the pain level of mothers in labor who apply Dzikir, the pain scale is immediately reduced from a scale of 6 to a scale of 1This is 


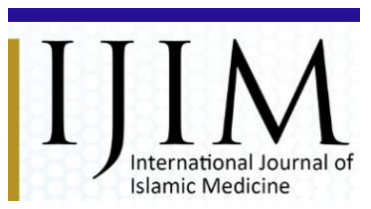

in line with research conducted by (Fadlilah, 2013), (Rahmawati, 2017), (Mualimah et al., 2020) which stated that the pain scale based on the first measurement before intervention and the second measurement after intervention there is a significant difference between the pain scale before intervention with the pain scale after intervention. Dzikir intervention to reduce maternity pain is very relevant to the role of midwives in carrying midwifery care for labor by looking at all aspects that patients have including biological, psychological, social, and spiritual aspects.

\section{CONCLUSION}

There was a significant decrease in the level of pain in maternity mothers after applying Dzikir. However, there has not been a percentage analyzed how much decline can be achieved, therefore it is necessary to further research with a greater number of research subjects and there is a comparison group.

\section{REFERENCES}

Corwin, E. J. (2009). Buku Saku Patofisiologi.

Fadlilah, M. (2013). Pengaruh Terapi Dzikir Terhadap Nyeri Persalinan Kala I Di Klinik Bersalin Budi Indah Palembang. Masker Medika, 1(1), 12-21.

Idris, M. (2016). Konsep Zikir Dalam Al-Qur’ an (Studi Atas Penafsiran M. Quraish Shihab). Universitas Islam Negeri Alauddin Makassar.

Lowdermilk, D. L., Perry, S. E., \& Cashion, M. C. (2013). Maternity Nursing-Revised Reprint. Elsevier Health Sciences.

Mander, R. (2010). Pain In Childbearing And Its Control: Key Issues For Midwives And Women. John Wiley \& Sons.

Mary, H. P. (2015). Dasar-Dasar Keperawatan Maternitas. Jakarta. Penerbit Buku Kedokteran Egc.

Mualimah, N., Nurbaeti, I., \& Palupi, P. (2020). The Effectiveness Of Dhikr To Intensity Of Pain During Active Phase In Mothers Getting Inducing Labour. Jurnal Keperawatan Padjadjaran, 8(2).

Newberg. A., \& Waldman, M. (2013). Born To Believe: Gen Iman Dalam Otak. In N. Ef (Ed.), Mizan.

Notoatmodjo, S. (2012). Metodologi Penelitian Kesehatan.

Olsen, M. (2017). Obstetric Care. Cambridge University Press.

Rahmawati, P. (2017). Perubahan Perbedaan Intensitas Nyeri Persalinan Kala 1 Antara Pasie Yang Menggunakan Teknik Relaksasi Dzikir Dengan Relaksasi Musik Di Rsam Bukittinggi Tahun 2017. Stikes Perintis Padang.

Saleh, A. Y. (2018). Berzikir Untuk Kesehatan Syaraf. Hikaru Publishing.

Sanusi, M. (2012). Berbagai Terapi Kesehatan Melalui Amalan-Amalan Ibadah.Jogjakarta: Najah.

Suryani, S. (2013). Salat And Dhikr To Dispel Voices: The Experience Of Indonesian Muslim With Chronic Mental Illness. Malaysian Journal Of Psychiatry, 22(1). 
Ai Nur Zannah, The effect of dhikr on anxiety and depression

$\mathrm{IJIM}$

IJIM, Vol 2, No 1, 2021

https://doi.org/10.37275/ijim.v2i1.22 